*Doutora e Mestre em Direito, Estado e Constituição(Universidade de Brasília). Procuradora Federal (Advocacia Geral da União). Professora Titular da Graduação e do Programa de Pós-Graduação, de Mestrado e Doutorado do Centro Universitário de Brasília - Uniceub)

** Graduação em Direito pela Universidade Paulista e Pósgraduando em Direito do Trabalho e Previdenciário no Centro Universitário de Brasília, UniCEUB.

E-mail:contatomaycon@, sempreceub.com

\section{RESPONSABILIDADE CIVIL AMBIENTAL DO ESTADO POR OMISSÃO E O PRINCÍPIO DO POLUIDOR-PAGADOR}

\author{
STATE'S CIVIL ENVIRONMENTAL RESPONSIBILITY AND THE \\ POLLUTER-PAYER PRINCIPLE
}

\section{Mariana Barbosa Cirne* Maycon Douglas de Miranda Silva**}

Como citar: CIRNE, Mariana Barbosa; SILVA, Maycon Douglas de Miranda. Responsabilidade civil ambiental do Estado por omissão e o princípio do poluidor-pagador. Revista do Direito Público, Londrina, v. 16, n. 2, p. 221-239, ago. 2021. DOI: $10.5433 / 24157-108104-1.2021 v 16 n 2 p .221$. ISSN: 1980$511 \mathrm{X}$

Resumo:AConstituição estabeleceunoart. 225 a responsabilidade compartilhada entre o Poder Público e a coletividade de defender e preservar o meio ambiente. Apesar disso, a conduta omissiva em matéria ambiental tem sido considerada como primeira resposta em casos de atividades lesivas imputadas a infratores desconhecidos, sob o argumento de que recai ao ente estatal o dever de preservar e tutelar o meio ambiente, especialmente através do exercício do poder de polícia. Neste contexto, este artigo defende, por meio de revisão bibliográfica e jurisprudencial, que a responsabilidade civil do Estado por omissão em face ao dano ambiental deveria ser subjetiva, pautando-se no princípio do poluidor-pagador. Pretende-se, com o trabalho, demonstrar que o texto constitucional de 1988 definiu como dever a proteção ao meio ambiente, tanto ao Estado quanto à sociedade, restando a responsabilidade primária pela reparação dos danos aferidos, através do princípio do poluidor-pagador, ao agente causador da atividade lesiva. Defende refletir sobre responsabilidade civil do Estado, aferindo-lhe uma natureza pautada na culpa, em contraponto ao principal responsável que se beneficiou do dano ou causou diretamente um prejuízo.

Palavras-chave: Responsabilidade civil; Meio ambiente; Omissão estatal; Dano ambiental; Responsabilidade subsidiária.

Abstract: The Constitution established in art. 225 the shared responsibility between the government and the community to defend and preserve the environment. Despite this, omissive conduct in environmental matters has been considered the first 
response in cases of harmful activities imputed to unknown offenders, under the argument that the duty to preserve and protect the environment falls to the state entity, especially through the exercise of police power. In this context, this article defends, by means of a bibliographical and jurisprudential review, that the civil liability of the State for omission in relation to environmental damage should be subjective, based on the polluter-pays principle. The purpose of this work is to demonstrate that the constitutional text of 1988 defined the protection of the environment as the duty of both the State and society, leaving the primary responsibility for repairing the damage to the agent that caused the damaging activity, through the polluter-pays principle. It advocates reflecting on the State's civil liability, attributing to it a nature based on guilt, in counterpoint to the principal responsible party that benefited from the damage or directly caused a loss.

Keywords: Civil Liability; Environment; State omission; Environmental Damage; Subsidiary Liability. 


\section{INTRODUÇÃO}

O presente artigo faz uma crítica à responsabilização civil objetiva do Estado por omissão em matéria de dano ambiental, firmada no Superior Tribunal de Justiça, a partir do princípio ambiental do poluidor-pagador e do direito ao meio ambiente ecologicamente equilibrado. Isso porque a Constituição estabeleceu a responsabilidade compartilhada entre o Poder Público e a coletividade de defender e preservar o meio ambiente (CIRNE, 2018), o que deve ensejar reflexos na interpretação dos tribunais sobre reparação civil.

Quanto ao dever de proteção estatal, a proteção ambiental foi determinada pela Constituição Federal de 1988, no artigo 23, como dever comum entre os entes federativos (MACHADO, 1996). Isso significa que a União, os Estados, o Distrito Federal e os Municípios devem atuar conjuntamente no intuito de proteger o meio ambiente. Essa premissa de zelo, contudo, não deve significar que o Estado deve ser, em regra, o responsável por reestabelecer o equilíbrio causado pelo dano ambiental (HUPFFER et al., 2012).

Neste contexto, o presente trabalho pretende fazer uma crítica à posição firmada pelo Superior Tribunal de Justiça (STJ) sobre o tema da reparação civil ambiental. Aquela corte tem entendimento firmado no sentido que o Estado deve responder pela reparação do dano ambiental, junto com o poluidor, em face da omissão estatal. Nas decisões, o STJ tem oscilado seu posicionamento entre admitir a responsabilidade subjetiva do Estado por omissão em face do dano ambiental e firmar a responsabilidade objetiva para esses casos (BARROSO, 2016; MOREIRA; LIMA; MOREIRA, 2019). Para defender a tese da responsabilidade civil objetiva, imputa ao Estado o dever de reparação em razão do descumprimento do dever legal de fiscalizar. Isso, contudo, parece desequilibrar as obrigações de defesa do meio ambiente, que são compartilhadas entre o Estado e a coletividade.

Diante desse contexto de responsabilidade compartilhada, a presente pesquisa objetiva desvendar a seguinte questão: A responsabilização civil objetiva do Estado por omissão materializa o princípio do poluidor-pagador e contribui para a concretização do direito ao meio ambiente ecologicamente equilibrado estabelecido no art. 225 da Constituição? A reflexão aqui pretendida está em saber se o meio ambiente será melhor protegido e preservado, caso o Estado seja responsabilizado solidariamente por possíveis danos que este vier a sofrer, mesmo sem ter contribuído para a existência da atividade lesiva.

$\mathrm{Na}$ finalidade de alcançar uma resposta para as indagações acima lançadas, por meio de uma pesquisa bibliográfica e jurisprudencial, o presente estudo se dividiu em quatro partes. A primeira delas falará sobre a responsabilidade compartilhada de proteção do meio ambiente no âmago da Constituição Federal de 1988, a partir do artigo 225 da CF/88. A abordagem se centrará no direito ao meio ambiente ecologicamente equilibrado e seus reflexos no entendimento judicial. No segundo tópico, haverá espaço para o dano ambiental, seguido da discussão sobre a responsabilidade civil do Estado, em sua interpretação no STJ. A quarta, e última parte, fará uma 
crítica à responsabilidade objetiva por omissão de fiscalização, a partir de uma leitura do princípio do poluidor-pagador e do direito ao meio ambiente ecologicamente equilibrado. Defende-se, aqui, que o dever de reparação do dano ambiental causado, com a utilização do princípio do poluidorpagador, só admite imputar a responsabilidade civil ao Estado excepcionalmente. A reparação do dano deve ser direcionada ao agente causador da atividade lesiva, que obteve benefício econômico através do prejuízo ao meio ambiente.

Como resultado, este estudo defende que a responsabilidade civil do Estado por omissão, apesar de se dizer objetiva, deve se pautar em um regime da responsabilidade subjetiva, demandando a verificação da culpa do serviço por imperícia, imprudência ou negligência, ou dolo, onde se observa a intenção estatal de omitir. De outra forma, onera-se toda a coletividade, o que não parece concretizar o direito ao meio ambiente ecologicamente equilibrado.

Explicado o caminho a ser trilhado, passa-se ao desenvolvimento.

\section{RESPONSABILIDADE COMPARTILHADA DE PROTEÇÃO AMBIENTAL}

O texto constitucional de 1988 elevou o direito ao meio ambiente ecologicamente equilibrado ao status de direito fundamental investido de transversalidade que transpõe e condiciona a atuação estatal, do indivíduo e da sociedade (SILVA, 2011, p. 142; BRASIL, 2006). Desse modo, vale destacar que a defesa do meio ambiente aparece na Constituição Federal de 1988 como aspecto impositivo e condicionador do exercício da liberdade econômica e da livre iniciativa, pois no art. 170, inciso VI, desde seu texto originário, consta estes deveriam observar a defesa do meio ambiente (BRASIL, 1988; BARROSO, 2016).

Isso significa que o exercício da livre iniciativa e da atividade econômica deve observar a defesa ambiental, sobretudo mediante tratamento distinto em observância ao impacto ambiental dos serviços e produtos e de seus procedimentos de prestação e criação. Em conformidade ao novo patamar constitucional que foi dado à defesa do meio ambiente, "eleva-se que o texto constitucional de 1988, no âmago de assegurar a plena proteção desse valor maior, aferiu a todos os entes federativos, sem distinção, o dever de desempenhar o poder de polícia em matéria de natureza ambiental." (LEITE, 2003, p. 156). Há, portanto, um dever estatal de compartilhado de proteção ambiental (CIRNE, 2013).

Tal raciocínio se pauta no art. 23 da Constituição de 1988, ao elucidar que é competência comum da União, dos Estados, do Distrito Federal e dos Municípios a proteção ao meio ambiente e o combate à poluição em todas as suas maneiras (MACHADO, 1996). Tal ponto revela a preocupação do constituinte em ampliar a proteção ao meio ambiente, seja este artificial, natural, do trabalho ou cultural (BRASIL, 2006), assegurando, assim, a imposição de atuação de, ao menos, um dos entes federativos (CIRNE, 2013).

Ocorre que a leitura deste dispositivo não pode ser realizada em separado ao contido no 
art. 225 da Constituição de 1988. em seu caput, expressamente trata sobre o meio ambiente com as seguintes ponderações: “este deve ser ecologicamente equilibrado, não bastando que exista por si; assim como deve ser de uso comum do povo; essencial à sadia qualidade de vida; sendo ainda um direito das presentes e futuras gerações." (BRASIL, 1988). Neste ponto, os estudos de Márcia Leuzinger (2002, p. 51) explicam que com o art. 225 a Constituição federal estabeleceu a "função ambiental, cuja titularidade foi outorgada ao Estado e à sociedade de um modo geral”. Vejamos: "§ $3^{\circ}$ As condutas e atividades consideradas lesivas ao meio ambiente sujeitarão os infratores, pessoas físicas ou jurídicas, a sanções penais e administrativas, independentemente da obrigação de reparar os danos causados.” (BRASIL, 1988).

Há, portanto, uma responsabilidade compartilhada entre o Poder Público e a coletividade de defender e preservar o meio ambiente (CIRNE, 2018). Cumpre evidenciar que a Constituição Verde avança ao afirmar que o meio ambiente ecologicamente equilibrado consiste em um direito de todos os indivíduos, direito este alheio a qualquer restrição ou limitação na verificação e abrangência deste termo. Desse modo, “é de se admitir como titular desse direito não apenas o brasileiro, nato ou naturalizado, como também o estrangeiro desde que residente no país, já que o direito ao meio ambiente é um direito fundamental intercomunitário." (LEITE, 2003, p. 158). Mas, perceba-se que o texto não apenas concedeu um direito em sentido amplo, mas ao mesmo tempo um dever. E esse dever não se restringe ao Estado. Sobre essa questão, merece destaque a tripla responsabilidade prevista no $\S 3^{\circ}$ do art. 225 , que engloba pessoas jurídicas ou físicas, independentemente de elas serem públicas ou privadas quanto à reparação civil, além da responsabilidade administrativa e criminal. Quanto à responsabilidade civil, portanto, trata da reparação do dano que pode ser imputada ao Estado e também ao particular.

Importa observar que o mesmo artigo 225 da Carta Magna de 1988 dispõe que o meio ambiente é um bem de uso comum do povo, mas isso não significa entendê-lo como simples bem público de domínio estatal. Em verdade, a realidade e as características do meio ambiente para a sociedade refletem um bem superior e difuso, sobre o qual o Estado desempenha a função de simples gestor em benefício da coletividade (LEITE, 2003). Em outras palavras, o Estado tem um papel indutor na prevenção e reparação do dano ambiental.

A redação do art. 225 (BRASIL, 1988), portanto, deixa nítido que é impositivo ao Estado e à coletividade o dever de proteger e preservar o meio ambiente. Todavia, sobressai, ainda, de forma evidente, que tal dever não pode ser imputado somente à figura estatal, seja por inviabilidade de instrumentos para supri-lo por si só, ou pela inserção do ser humano no meio ambiente, sendo este capaz de protegê-lo ou destruí-lo (HUPFFER et al., 2012).

Para tanto, a própria disposição constitucional denota verdadeira obrigação entre gerações, motivo a reforçar que o dever de preservação e proteção é tanto uma imposição à sociedade e seus componentes individuais quanto ao Estado. O supracitado ponto, evidentemente, possui o foco na atuação coletiva, em grupo ou individual, uma vez que, como uma obrigação intergeracional, está vinculado ao dever que recai à presente geração de proteger e preservar o meio ambiente para as seguintes. Sobre o assunto, o Supremo Tribunal Federal já assentou o meio ambiente como direito 
fundamental, na ADI-MC 3540-DF, ao enquadrá-lo na terceira geração de direitos fundamentais, sendo refletido naqueles de natureza transindividual. Há, portanto, um compartilhamento de responsabilidade que não deve ser restrito ao Estado, sob pena de desequilibrar a sua gestão.

O meio ambiente, por sua natureza e relevância, não se restringe a uma localidade, espaço ou parte do Brasil. Refere-se ao mundo em sua completude, sendo indispensável uma conscientização ecológica como reflexo da proteção interconstitucional, buscada por todas as sociedades. Mediante essa conjuntura, e verificada a importância dos interesses envolvidos, resta nítido que a proteção do bem jurídico ambiental é fundamental (BENJAMIN, 2015), pois o futuro e o bem estar de todos os indivíduos possuem relação direta com o meio ambiente (CARVALHO, 2008; SARLET, FENSTERSEIFER, 2014).

Com tais colocações, espera-se ter demonstrado que, de um lado, a proteção ambiental é um dever de relevância difusa e transindividual. De outro lado, no entanto, não se restringe a uma obrigação estatal (União, Estado, Distrito Federal e Municípios), mas sim a obrigação compartilhada com a coletividade (em uma visão ampla que não se restringe ao conceito de cidadão). Explicados os principais pontos da Constituição ambiental, passa-se em seguida para um estudo sobre o dano ambiental.

\section{O DANO AMBIENTAL}

Na seara da responsabilidade civil, não há como falar em reparação sem a ocorrência do dano (PEREIRA, 2000). A expressão dano compreende uma das bases fundamentais da responsabilidade civil, de forma que se faz essencial sua definição. $\mathrm{O}$ dano se traduz no prejuízo aferido a algum indivíduo por um terceiro, seja pela ação ou omissão, encontrando-se este obrigado ao ressarcimento, resultando na modificação de uma estabelecida situação, seja esta material, moral ou jurídica. Conforme Antunes (2006, p. 198) “apenas se incluem as alterações negativas, pois não existe dano se as condições forem modificadas de forma positiva, para melhor. É a variação, moral ou material, negativa, que deverá ser considerada de modo que se possa efetivar o ressarcimento."

Ao permear os estudos sobre o dano ambiental, cumpre ressaltar que a legislação não teceu sua definição de modo expresso. Isso, no entanto, tem uma justificativa. A rigidez conceitual seria incompatível com o crescimento da evolução tecnológica e do potencial lesivo existente na sociedade contemporânea. A complexidade dos danos ambientais não recomenda essa restrição. De um lado, "caso houvesse uma conceituação extremamente minuciosa viria a diminuir o campo de incidência da norma. Por outro lado, caso o conceito viesse carregado de carga excessiva poderia obstar o próprio desenvolvimento (CARVALHO, 2008, p. 79). Tal constatação indica a melhor escolha de manutenção quanto à sua conceituação.

Verifica-se, desse modo, que o dano ambiental possui uma definição complexa e em aberto. $\mathrm{O}$ dano ambiental parece significar uma violação a um dever jurídico, garantido a todos os indivíduos, de preservar e proteger o bem jurídico refletido no ambiente ecologicamente equilibrado. O dano "ocorre quando o limite aceitável de degradação ambiental é ultrapassado, 
tornando o ambiente insuportável ao homem.” (ALMEIDA, 2018, p. 69). Isso porque o meio ambiente é fundamental para as condições fundamentais humanas. As referidas condições, por seu turno, influenciam diretamente na saúde humana, podendo ocasionar severos prejuízos na qualidade de vida e no desenvolvimento individual e coletivo. Exatamente por isso, "a degradação ambiental coloca em risco direto à vida e a saúde das pessoas, individual e coletivamente considerados, assim como a própria perpetuação da espécie humana.” (TEIXEIRA, 2000, p. 15).

Como não se verifica expressamente uma definição legal de dano ambiental, é possível extrair tal conceito do art. $3^{\circ}$, II e III, da Lei $n^{\circ}$ 6.938/81 (BRASIL, 1981), que traz a definição da degradação da qualidade ambiental como sendo a modificação contrária às características do meio ambiente e a de poluição. Um conceito é gênero, sendo o outro espécie, demonstrando a complexidade e a abrangência do conceito de dano ambiental.

A definição de dano ambiental, em conformidade aos princípios que regem o assunto, sobretudo o Princípio do Limite, junto às definições legais de degradação e de poluição, permite concluir que "o dano aparece no plano ecológico não somente quando produz destruição, mas também quando, por sua repetição e insistência, excede a capacidade natural de assimilação, de eliminação e de reintrodução dos detritos no ciclo biológico.” (STEIGLEDER, 2011, p. 233). Isso significa que pela noção do dano ambiental, a responsabilização civil ocorre não só por ato ilícito, mas também relativamente ao ressarcimento de prejuízos em que não se cogita da ilicitude da ação do agente ou até mesmo da ocorrência de ato ilícito (HUPFFER et al., 2012). Um aspecto relevante do dano ambiental é que em regra ele é eivado de licitude, pois ainda que a atividade possua licença ambiental, esta não está isenta à reparação pela degradação e/ou poluição do meio ambiente (OLIVEIRA, 2007, p. 144). Perceba-se, então, que para o debate sobre a responsabilização estatal, a reparação do dano pode decorrer de ato lícito ou ilícito.

Nesse contexto, ainda que se manifeste de modo mais ostensivo e explícito, a partir de atentados a bens ambientais e seus componentes, o dano ambiental, em verdade, será sempre mais abrangente, ao passo que acaba por atingir o emaranhado de condições, interdependências e relações que viabilizam a vida de uma forma geral. Isso, inegavelmente, exige uma ampliação de sua noção de reparação (HUPFFER et al., 2012). Tal visão, contudo, não pode ser apartada da noção constitucional de responsabilidade compartilhada de proteção constitucional.

Explicada a premissa de que o dano ao meio ambiente se distingue, em muitos pontos, do dano tradicional, envolvendo o lícito e o ilícito, além da complexidade do meio ambiente, parte-se para os pressupostos da responsabilidade civil ambiental, para alcançar o debate sobre a responsabilidade do Estado.

\section{A RESPONSABILIDADE CIVIL DO ESTADO POR DANO AMBIENTAL}

A responsabilidade civil do Estado está esculpida no $\S 6^{\circ}$ do artigo 37 da Constituição Federal (BRASIL, 1988), o qual determina que as pessoas jurídicas de direito público respondam objetivamente pelos danos que os seus agentes, nessa qualidade, causarem a terceiros. Isso significa 
que para se configurar a responsabilidade civil do Estado é necessário que se demonstre o nexo de causalidade entre os danos causados e a conduta tanto das pessoas jurídicas de direito público quanto das de direito privado prestadoras de serviço público, sendo desnecessária a prova de culpa (SANTOS; BRASIL, 2018).

$\mathrm{O}$ ato, no entanto, não precisa ser ilícito, bastando a comprovação do dano e o nexo causal entre a atividade estatal e o resultado danoso (HUPFFER et al., 2012). Além do art. 37, $\S 6^{\circ}$, da Constituição de 1988, o Código Civil de 2002 (BRASIL, 2002), no art. 43, também dispõe sobre a responsabilidade civil do Estado pelas condutas de seus agentes, quando nessa qualidade ocasionarem danos a outrem. Mais do que isso, a Lei $n^{\circ}$ 6.938/81 (BRASIL, 1981) estabeleceu a responsabilidade objetiva, em seu art. $14, \S 1^{\circ}$, o que enseja a adoção pela teoria do risco integral. Desse modo, verifica-se que o sistema jurídico brasileiro preza pela responsabilidade objetiva, sendo adotada a teoria do risco (BRASIL, 1988).

A ideia de reparação do dano, que é o cerne da reparação civil, merece se pautar na identificação do sujeito passivo e na devida reparação danosa (PEREIRA, 2000, p. 11). Busca-se, em regra, na esfera privada, fazer uma análise de culpa para obrigar o "infrator ao pagamento de uma compensação pecuniária à vítima, caso não possa repor in natura o estado anterior de coisas." (GAGLIANO; PAMPLONA FILHO, 2003, p. 9). Isso não significa que esse infrator não possa ser o Estado. Ocorre que o debate a ser travado aqui está em tentar conciliar essa responsabilidade objetiva do Estado, mesmo na hipótese de ele não ter cometido qualquer ilícito. Como equiparar a omissão estatal do dever de fiscalizar à situação do infrator.

Em linhas gerais, a responsabilidade civil busca orientar que, em ocorrendo um evento danoso, o sujeito passivo possui o dever de reparar, independentemente de o fundamento ser a culpa ou não. No caso do Estado, conforme o art. 37, $\S 6^{\circ}$, isso independe de culpa. Ocorre que, aqui, o papel do infrator é diferente do desempenhado pelo Estado.

Apesar disso, a jurisprudência do STJ permanece responsabilizando-os, de maneira objetiva, solidariamente. Os estudos de Moreira, Lima e Moreira (2019), sobre os julgados do STJ pautados no princípio do poluidor-pagador identificou 19 decisões sobre a responsabilidade civil ambiental do Estado por omissão. Nestas decisões, apesar de identificada parte das decisões que se valem do poluidor-pagador com a finalidade de tentar suavizar a responsabilização estatal na condição de poluidor direto, aquela Corte ainda não parece ter firmado posição sobre o tema. A solução encontrada por aquela corte perece ter sido a de "a responsabilidade civil do Estado por omissão, ainda que seja objetiva, não impede a execução subsidiária do Estado" (BARROSO, 2016, p. 17). Sobre a posição da jurisprudência, o estudo de 208 julgados, sendo 19 deles sobre o objeto deste artigo, resume a posição do STJ:

Se não há dúvida sobre o caráter objetivo da responsabilidade civil ambiental do Estado por atos comissivos - seja em razão dos artigos 14 , parágrafo $1^{\circ}$, e $3^{\circ}$, IV, da Lei 6.938/1981, seja por conta do artigo 37, parágrafo $6^{\circ}$, da Constituição Federal - o mesmo não acontece quando omissão estatal dá causa ou contribui para a causação de dano ao meio ambiente. Nesta hipótese, argumenta-se tanto 
no sentido de que a responsabilidade civil ambiental do Estado por omissão seria, em regra, subjetiva (tese que tem predominado sobre a responsabilidade civil do Estado em geral),44 quanto em defesa de tese de que prevalece a previsão da responsabilidade constante em lei específica (que, no caso de reparação por danos ambientais, dispõe, expressamente, que também por omissão - ou na condição de poluidor indireto - o Estado responde objetivamente) (MOREIRA; LIMA; MOREIRA, 2019, p. 388)

O Estado, portanto, mesmo que seja o poluidor indireto, permanece respondendo objetivamente, como se o seu dever de fiscalização o equiparasse ao infrator. É neste ponto que este trabalho pauta a sua crítica e pretende contribuir com o debate.

Segundo os autores, dentre as jurisprudências coletadas no estudo, merecem evidência aquelas que trataram de modo diverso a responsabilização ambiental do Estado por omissão, com destaque aos Recursos Especiais de $n^{\circ}$ 647.493-SC e 1.071.741-SP. No primeiro caso, segundo Moreira, Lima E Moreira (2019, p. 388-389):

O MPF ajuizou ação civil pública em face de diversas empresas mineradoras e da União Federal em razão de danos ambientais decorrentes de atividade minerária. Embora a União tenha siso condenada solidariamente com as empresas diretamente causadoras dos danos ambientais com base na sua responsabilidade subjetiva (com culpa), deve-se destacar que seu argumento de defesa foi no sentido de ver reconhecida alegada ilegitimidade passiva, tendo utilizado para fundamentar a tese a própria orientação do princípio do poluidor-pagador. No primeiro caso, o MPF ajuizou ação civil pública em face de diversas empresas mineradoras e da União Federal em razão de danos ambientais decorrentes de atividade minerária. Embora a União tenha siso condenada solidariamente com as empresas diretamente causadoras dos danos ambientais com base na sua responsabilidade subjetiva (com culpa), deve-se destacar que seu argumento de defesa foi no sentido de ver reconhecida alegada ilegitimidade passiva, tendo utilizado para fundamentar a tese a própria orientação do princípio do poluidorpagador. Explica-se. A União Federal argumentou que, ao ser responsabilizada - objetivamente - por danos com os quais não contribuiu diretamente, acabaria por submeter a coletividade a prejuízo em dobro: o primeiro identificado no dano ambiental propriamente dito - e suas consequências diretas em perda de qualidade de vida para a população - e o outro representado pelo aporte de recursos públicos para fazer frente à degradação ambiental - o que significaria verdadeira socialização das perdas e privatização dos ganhos (vez que os poluidores diretos acabariam por não arcar com os ônus financeiros da reparação), em desrespeito ao PPP. A segunda Turma do STJ condenou a União com base na sua omissão culposa - em descumprimento de dever legal de fiscalizar atividades extrativas de carvão mineral (poluidor indireto), considerando-a solidariamente responsável com as sociedades mineradoras (poluidores diretos) e frisando, entretanto, a necessidade de que, uma vez instado a pagar, o ente público teria, não somente o direito, mas o dever de procurar o ressarcimento total das quantias despendidas (“dever de regresso"). Este acordão é importante porque deu início à discussão sobre como a orientação do princípio do poluidor-pagador (para evitar socialização de ônus e privatização de bônus) deve ser considerada nas ações civis públicas ambientais em que figuram como réus, além do poluidor direto, o Estado, como 
poluidor indireto.

O acórdão do STJ mencionado condenou a União com fundamento na sua omissão culposa, inaugurando uma divergência que merece aprofundamento. A responsabilidade objetiva, se aplicada na omissão de fiscalização sem ponderações, equiparará o Estado ao poluidor, o que não parece ser a pretensão constitucional da responsabilidade compartilhada.

Portanto, verifica-se que a excepcionalidade da aceitação pelo Estado do custeio para a reparação de dano em matéria ambiental, que seria aferida somente nas situações em que não tenha sido realizável a identificação do agente causador direto da atividade lesiva ou fique constatado que a empresa não possui condição imediata de arcar a reparação em virtude de sua completa carência econômica, parece ser o melhor caminho. Contudo, nessas situações, não cumpre aferir que a responsabilidade não seja do agente causador, somente será imposto ao ente estatal a antecipação desse dispêndio em benefício da coletividade. Assim, nas referidas situações, deverá o Estado se voltar contra o particular causador do dano assim que possível, para o pleno ressarcimento dos custos realizados na reparação do dano ambiental. Neste debate, o princípio do poluidor-pagador pode ocupar papel de destaque para essa revisão de entendimento, o que se espera de um judiciário socioambientalmente responsável (BARBOSA, 2008).

O fundamento da responsabilidade civil estatal por danos ocasionados aos indivíduos, de maneira geral, reside no princípio da repartição do ônus ou encargos sociais, de modo que, quando algum indivíduo sofre ônus superior aos demais, ocorre a ruptura do equilíbrio que, para ser estabilizado, impõe que o Estado indenize, com recursos das finanças públicas, a vítima do dano. O dano aferido pela Administração a um particular "é uma variação de encargo público que não deve recair somente sobre um indivíduo, mas que deve ser dividido entre todos, o que ocorre pela indenização da vítima, cujo ônus definitivo, através de imposto, cabe aos contribuintes." (PORFÍRIO JÚNIOR, 2002, p. 20). Isso, contudo, precisa ser avaliado com cautela em se tratando da reparação de dano ambiental.

A responsabilidade do Estado é mais extensa que a dos particulares, pois os deveres públicos colocam o Estado permanentemente na posição de obrigações variadas que é obrigado a cumprir, atuando, muitas vezes, por meio de atos de polícia, restringindo ou condicionando uso de bens, gozo de direitos e exercício de atividades e dispondo, para tanto, do uso natural da força. Além disso, os administrados não têm como evitar os perigos do dano provenientes da ação do Estado, o que determina a contínua extensão de sua responsabilidade (MELLO, 2002, p. 838).

O responsável pelo dano possui o dever de reparação, sendo este o mais abrangente possível. A referida reparação, nada mais é que a procura de um determinado valor proporcional ao dano causado por aquele que realizou a conduta ilícita, não importando se foi por um mero desaviso ou descuido. O diferencial aqui está nas limitações ao dever de fiscalizar dentro de uma competência comum ambiental. 
Em se tratando da responsabilidade civil em matéria ambiental, o Estado, como qualquer pessoa física ou jurídica, pode ser responsabilizado pelos prejuízos ocasionados ao meio ambiente, seja por omissão ou através da concessão inadequada de um licenciamento ambiental. Desse modo, este estudo não pretende afastar a noção de que o Estado é responsável pelo dano ocasionado por seus agentes. O debate aqui está na omissão do dever geral, sem se observar se houve culpa do Estado quanto à ação para resolver o problema, contribuindo para o agravamento do dano.

Há de se concordar que por realizar atuações que prejudicam o meio ambiente, como a edificação de represas, estações de tratamento de esgoto, implementação de usinas hidrelétricas e atômicas sem a realização de uma pesquisa prévia sobre o impacto ambiental, o Estado pode ser responsável pelos prejuízos que - de modo direto - ocasionar ao meio ambiente através de suas funções típicas (SIRVINSKAS, 2010, p. 285).

O ponto aqui em debate, no entanto, está na configuração da responsabilidade civil do Estado por omissão decorrente do poder de polícia, o que merece cautela.

Isso porque o Poder Público também pode ser responsável quando se omite no dever constitucional de proteger o meio ambiente, como "na falta de fiscalização, inobservância das regras informadoras dos processos de licenciamento, inércia quanto à instalação de sistemas de disposição de lixo e tratamento de esgotos, entre outros deveres na proteção do meio ambiente." (MILARÉ, 2008, p. 536). Esse entendimento, no entanto, coloca-o em posição equivalente ao do infrator, o que princípio do poluidor-pagador não parece orientar a fazê-lo.

Dessa forma, os casos em que a omissão estatal ocasiona o evento danoso ocorrem quando a omissão ou a ausência de serviço funciona com falhas ou de modo tardio. Nessa perspectiva, o Poder Público, mesmo não sendo o causador do dano, não o evita. Ocorre que, esta aplicação não merece ser implementada, como defendido, neste trabalho, de maneira solidária com o infrator, pois nem sempre o Estado teria ciência dos danos ambientais em andamento. A complexidade desses danos demonstra o quanto essa noção é difícil.

Isso porque a responsabilização automática do Estado - sem a observância do dolo ou culpa - por todo prejuízo ambiental -, em regime de solidariedade com o empreendedor, "onera a própria coletividade lesada em seu direito ao meio ambiente ecologicamente equilibrado." (CARVALHO, 2011, p. 33). Em outras palavras, a sociedade arcará, em última análise, com os dispêndios da reparação do meio ambiente.

Não se afasta com isso a essencialidade de o Estado exigir de seus entes um desempenho proativo, não apenas na intenção de evitar o dano ambiental, mas também de proteger de maneira efetiva o meio ambiente. O problema parece existir ao tratar essa responsabilidade do Estado de maneira objetiva e não subjetiva. A responsabilidade do Estado em relação à tutela do meio ambiente exige que ele assuma uma postura mais ativa e de atuação preventiva, no sentido de evitar a ocorrência do dano ambiental. Neste ponto, não há dúvida. Isso contudo, não pode significar uma equiparação entre o Estado e o Infrator. Há de se recordar que "Os sempre escassos recursos econômicos do Poder Público podem ser muito melhor empregados dessa maneira do que se usados na tentativa de reparar ou indenizar os danos que já tenham acontecido. Além disso, não 
há como se reparar o esgotamento de recursos naturais. (PORFÍRIO JÚNIOR, 2002, p. 402).

Em outras palavras, a responsabilidade civil objetiva do Estado por omissão pauta-se na comprovação de que o Estado, por ser mais poderoso que o administrado, teria que lidar com um risco natural oriundo das volumosas atividades por ele desempenhadas em contrapartida aos inúmeros poderes a ele conferidos. Ocorre que, ao se onerar o Estado, equiparando-o ao infrator na reparação do dano, não se deixa de reduzir a sua capacidade de atuação preventiva. Isso porque a condenação do ente estatal implicará o pagamento da indenização pelo dano de modo compartilhado por toda a sociedade, já que esta, em última análise, seria a desfrutadora dos poderes estatais.

Por isso, é preferível que o ente estatal apenas seja responsabilizado na impossibilidade de se executar o patrimônio do agente que lucra de forma efetiva com a atividade danosa, "a fim de impedir que a sociedade, que nutre os cofres públicos, seja obrigada a arcar com o dano do qual foi vítima." (STEIGLEDE, 2011, p. 199).

Há quem defenda que "se houver dano ou sacrifício especial ao ambiente, a responsabilidade estatal pelo licenciamento ou autorização será objetiva, sob o fundamento do princípio da igualdade, procurando-se garantir uma equânime repartição dos ônus provenientes dos atos ou efeitos lesivos, evitando que alguns suportem prejuízos ocorridos por ocasião ou por causa de atividades desempenhadas no interesse de todos" (MELLO, 2010, p. 113). Ocorre que, ao decidir dessa forma, retira-se do infrator a responsabilidade e a coloca sobre os ombros de toda a coletividade, o que não parece respeitar o princípio do poluidor-pagador, como será explicado em seguida.

\section{O DEVER DE REPARAÇÃO DO DANO AMBIENTAL E O PRINCÍPIO DO POLUIDOR- PAGADOR}

O princípio do poluidor-pagador, que norteia a responsabilização e a prevenção em matéria de dano ambiental (MOREIRA; LIMA; MOREIRA, 2019), prega a responsabilidade de prevenir e reparar os danos ambientais ao causador-poluidor, tendo em vista que este se utiliza de recursos naturais no objetivo de alcançar lucros, os quais são privatizados, de maneira contrária aos danos ambientais, os quais são internalizados e arcados por toda a sociedade. Está previsto entre os objetivos da Política Nacional do Meio Ambiente, art. 4, inciso VII, quanto trata da "imposição, ao poluidor e ao predador, da obrigação de recuperar e/ou indenizar os danos causados e, ao usuário, da contribuição pela utilização de recursos ambientais com fins econômicos." (BRASIL, 1981). Encontra, portanto, amparo normativo no ordenamento brasileiro.

O princípio do poluído-pagador defende que o "poluidor tem o dever de arcar com as despesas de prevenção dos danos que a sua atividade meio possa vir a ocasionar ao meio ambiente, dessa forma, imputa a ele se utilizar das formas necessárias a prevenção do dano." (FIORILLO, 2009, p. 37). Trata-se de princípio de natureza jurídico econômica, isto é, norteia-se para atribuir a aqueles que causaram alguma degradação ao meio ambiente o ônus oriundo aos reflexos de 
sua conduta lesiva, incluindo-o ao montante final de seu produto fim. O princípio do poluidorpagador é traduzido "na obrigação do empreendedor de internalizar as externalidades negativas dos custos da produção (como a poluição, a erosão, os danos à fauna e à flora, etc.), assim como daquele que causa degradação ambiental de arcar com os custos de sua prevenção e/ou reparação.” (LEUZINGER; CUREAU, 2008, p. 98). Desse modo, insere-se na questão das externalidades da atividade.

Através do princípio, o foco de responsabilização por danos ao meio ambiente é aferido, quando não exclusivamente, ao empreendedor-particular que atua na intenção única e exclusiva de obter lucros e somente acidentalmente preservando e respeitando o meio ambiente. De maneira contrária, o ente estatal, por estar ligado aos ditames legais e ao interesse coletivo, está intrinsecamente voltado, entre outras finalidades, a defender o meio ambiente e a sociedade, só acidentalmente ocasionando lesões a tais âmbitos. Nesse sentido:

O princípio do poluidor-pagador pretende redistribuir equitativamente as externalidades ambientais. Defende que, se as externalidades são suportadas pela sociedade em prol do lucro do responsável pelo produto que, em alguma fase da cadeia de mercado, é degradante para o meio ambiente ou diminui o exercício do uso comum dos componentes ambientais, nada mais justo que todos os custos de prevenção, precaução, correção na fonte, repressão penal, civil e administrativa, que são despendidos pelo Estado (ficção jurídica representativa do povo), a quem incumbe a gestão dos componentes ambientais, sejam infligidos ao responsável pelas externalidades ambientais (RODRIGUES, 2008, p. 167).

Em suma, não se pode perder de vista que a responsabilização do Estado significa imputar esse ônus a toda a coletividade. O processo produtivo ocasiona danos que, na inobservância desse princípio, acabam por recar no Estado e, de modo consequente, à sociedade, ao passo que o lucro é obtido somente pelo agente causador. A fim de reduzir esse custo, que poderia ser arcado pela sociedade, é preciso que se imponha a sua internalização, fundamentada na obrigação de que o responsável arque com os custos da prevenção e/ou reparação (LEUZINGER; CUREAU, 2008, p. 98).

Não se olvida aqui a relevância das atividades econômicas para o bem-estar social e para assegurar à sociedade a aproximação a bens e a serviços impulsionadores da qualidade de vida. Isso não afasta, contudo, a conclusão de que o encargo de reparar o dano ambiental recaia prioritariamente a quem dele obtém vantagem direta com finalidades econômicas, e não ao Estado, em igualdade de condições.

Não devem ser os contribuintes obrigados a custear, através dos impostos que pagam, as medidas tomadas pelos poderes públicos para a proteção do ambiente, sejam elas medidas legislativas, administrativas ou materiais. Pelo contrário, deverão, a seu ver, serem criados fundos gerais ou especiais alimentados pelos poluidores, dos quais sairiam as verbas necessárias à realização das despesas de proteção ao ambiente. Seria uma política de "equilíbrio do orçamento ambiental" ou de "reciclagem de fundos". (ARAGÃO, 2007, p. 59) 
Segundo Canotilho (1993, p. 288), ao se verificar os reflexos justificadores dos atos permissivos emanados pelo Estado e que poderiam levar a uma isenção do agente causador por danos aferidos ao meio ambiente, pondera que, "mesmo nessas situações, não existe um deslocamento do dever de indenizar do particular lesante para o Estado autorizador das atividades lesivas." Um entendimento nesse sentido teria, no direito ambiental, efeitos severos, uma vez que implicaria, internamente, que o princípio do poluidor-pagador se alterasse para o princípio do Estado pagador de poluições permitidas. Isso não se compatibiliza com o Direito ao meio ambiente ecologicamente equilibrado, que tem como eixo central a noção de equilíbrio ecológico (CIRNE, 2018).

Canotilho (1993, p. 289) ainda conclui que "uma breve incursão pelo direito positivo demonstrar-nos-á que a orientação é na intenção de impor a compensação do sacrifício ao particular diretamente causador do sacrifício de bens ou direitos fundamentais de terceiros lesados." Nesse cenário, este artigo aponta que é intrínseco ao princípio do poluidor-pagador que, ainda que se trate de possível omissão estatal, a responsabilidade civil deverá ser aferida - de maneira prioritária - ao particular. É necessário eliminar o falso entendimento de que o Estado tudo pode e deve custear preferencialmente, ou em condições isonômicas, com o agente causador dos prejuízos ao meio ambiente, seja porque o Estado não se faz presente em todos os lugares, seja porque o dever de custear com os dispêndios da recuperação ambiental há de ser suportado pelo causador do dano, sobretudo o seu beneficiário econômico.

Como fator relevante para respaldar as conclusões da presente pesquisa, já que se almeja apresentar que não é aceitável a responsabilização, ou ao menos o custeio principal, do Estado em ocasiões que distanciam a uma atuação padrão e suficiente deste, vale ressaltar que pelo princípio do poluidor-pagador denota-se ao empreendedor causador, verdadeiro beneficiário econômico dos danos aferidos ao meio ambiente e à sociedade, o dever de trazer para si os reflexos sociais externos oriundos de sua conduta lesiva.

Não se pode olvidar que existem acontecimentos que fogem ao funcionamento normal e esperado do Estado, isto é, situações que presumiriam determinada ubiquidade ou perfeição do Estado-completamente ilógica e inaceitável, mesmo que para padrões excelentes. Nessas situações, quando muito, a responsabilidade apenas pode ser ponderada sob o viés da responsabilidade civil subjetiva. "A falta de estrutura estatal que impede a onipresença do Estado para prevenir danos ao meio ambiente não pode ser invocada como supedâneo para a aplicação da responsabilidade objetiva em casos que decorram do dever de vigilância do Estado em situações clandestinas. Até porque o Estado não pretende, nem pode estar em todos os potenciais lugares nos quais se pretenda praticar danos ambientais (LEUZINGER; CUREAU, 2008, p. 94).

Dessa maneira, é necessário, no mínimo, que exista uma rigorosa análise casuística que apresente o grau de falha do Estado, sobretudo quando exista responsável direto pelo prejuízo que o tenha realizado com propósito direto e finalidades próprias. À vista disso, o que se pretende é que os legitimados para a ação civil pública ou ainda as pessoas em suas ações pontuais para 
a reparação do dano ambiental causado, prezem pela instauração das demandas exclusivamente contra o particular, sendo este o causador direto do dano.

Não cumpre impor ao ente estatal, dessa forma, uma responsabilidade civil por danos ambientais, em caso de omissão, quando este não tenha categoricamente contribuído para o dano, pois isso seria imputar sobre a sociedade o ônus por ela sofrido com o evento lesivo. É necessário, em benefício dos administrados, que a reparação ambiental seja preferencialmente custeada pelo seu causador direto e beneficiário econômico.

Nesse contexto, as lições de elevam que:

Ou seja, se não há obrigação legal de impedir um certo evento danoso, não se pode imputar ao Estado a responsabilidade por um dano que não causou, surgindo a responsabilidade apenas quando presentes a culpa, por negligência, imprudência ou imperícia no serviço, ou o dolo, intenção de omitir-se, em situação que demandasse atuaçã o do Estado segundo um certo padrão de eficiência capaz de obstar o evento lesivo. E esse padrão normal de atuação do Estado deverá ser apurado em função do meio social, do estágio de desenvolvimento tecnológico, cultural, econômico e da conjuntura da época. Ele diz respeito às possibilidades reais médias do ente público naquele determinado momento (MELLO, 2002, p. $855)$.

No caso de constatação da plena ausência de condições de responsabilizar o indivíduo causador do evento lesivo, não pela difusão do dano, em vista da complexidade de mensurar a responsabilidade de cada causador ou a quantidade de causadores, mas sobretudo pela completa impossibilidade de determinar qualquer nexo entre o dano e algum causador ou pela total incapacidade financeira do indivíduo para prover o reparo ambiental, é de se impor ao Estado assumir com os custeios daqueles danos que direta ou indiretamente tenha ocasionado. Nas supracitadas situações, deve o Estado, assim que possível, voltar-se contra ao indivíduo causador para alcançar o ressarcimento ao erário, uma vez que se trata de recuperação não passível de prescrição, com fulcro no art. 37, § 5. ${ }^{\circ}$, da CF/88 (BRASIL, 1988).

Portanto, mediante tais ponderações, a responsabilidade civil do Estado deve estar ligada ao princípio do poluidor-pagador, incluindo-se o dever de reparação do Estado em ocasiões que não conflitem as disposições contidas no art. 225 da Carta Magna de 1988.

\section{CONSIDERAÇÕES FINAIS}

Com a realização do presente estudo, pretendeu- se contribuir com um debate em andamento no Superior Tribunal de Justiça, quanto à responsabilização estatal objetiva por omissão, equiparando-se a posição do infrator e do Estado. Ao apresentar a responsabilidade compartilhada entre a Coletividade e o Poder Público, inserida no art. 225, este trabalho almejou reestabelecer o equilíbrio destas obrigações ambiental. O Estado não pode ser o principal responsável pela reparação do dano, sob pena de ofensa ao direito ao meio ambiente ecologicamente equilibrado, 
que se pauta na noção de equilíbrio.

O conceito de dano ambiental é complexo e amplo, como precisa ser a tutela de proteção ambiental, mas isso não significa, outra vez, o direcionamento do problema de maneira restrita ao Estado. Com a ajuda de pesquisas sobre as decisões do STJ sobre a reparação de dano ambiental por omissão, este artigo pretende aprofundar a leitura que endossa uma investigação subjetiva sobre a atuação estatal, sustentando-se no equilíbrio dos ônus proposto pelo princípio do poluidorpagador.

Como resultado, a pesquisa observou que a responsabilidade civil do Estado por omissão em matéria ambiental não deve ser dirigida ao Poder Público quando este operou dentro de condições normais de atuação ou o fato seja completamente clandestino, a ponto de afastar uma possível atuação do Estado na prevenção do dano. Defende-se, aqui, que postura que o Estado, em face ao dano ambiental aferido por omissão estatal, pode sujeitá-lo à reparação desde que tenha diretamente causado a atividade lesiva ou não tenha agido em ensejo a preveni-lo quando o risco era de seu conhecimento e havia o dever de evitá-lo.

Assim, mesmo que se denote a responsabilidade civil ao Poder Público por sua omissão, esta merece se valer de um regime da responsabilidade subjetiva, exigindo-se a constatação da culpa do serviço, seja por imperícia, negligência e imprudência na prestação, ou dolo, no qual se vislumbra a intenção de omitir. Dessa forma, é essencial que a execução do patrimônio, para alcançar a recuperação do dano ambiental, recaia preferencialmente sobre os bens do agente causador e apenas de modo subsidiário ao Estado.

Portanto, conclui-se que nos casos em que seja inconcebível aferir a responsabilidade pela reparação do dano ambiental ao agente causador direto, os dispêndios da recuperação deverão recair sobre o Estado, lhe sendo exequível posteriormente, ação de regresso para alcançar o ressarcimento dos custos auferidos. Assim, tem-se que a presente conclusão se compatibiliza com a máxima constitucional de assegurar, em caso de dano, a imediata e completa reparação do meio ambiente.

\section{REFERÊNCIAS}

ALMEIDA, Maria Pilar Prazeres de. O dano moral ambiental coletivo. Florianópolis: Tirant to Blanch. 2018.

ANTUNES, Paulo de Bessa. Direito ambiental. 9. ed. Rio de Janeiro: Lúmen Júris, 2006.

ARAGÃO, Alexandra. Direito constitucional do ambiente da União Europeia. In: CANOTILHO, José Joaquim Gomes; LEITE, José Rubens Morato (org.). Direito constitucional ambiental brasileiro. São Paulo: Saraiva, 2007.

BARBOSA, Claudia Maria. Reflexões para um judiciário socioambientalmente responsável. 
Revista da Faculdade de Direito - UFPR, Curitiba, n. 48, p. 107-120, 2008.

BARROSO, Ricardo Cavalcante. A Responsabilidade civil do Estado por omissão em face do dano ambiental. Revista de Direito Ambiental, São Paulo, v. 63, p. 203-238, jul./set. 2011

BENJAMIN, Antônio Herman de Vasconcellos e. Constitucionalização do ambiente e ecologização da Constituição brasileira. In: CANOTILHO, José Joaquim Gomes; LEITE, José Rubens Morato (org.). Direito Constitucional Ambiental Brasileiro. 6. ed. São Paulo: Saraiva, 2015, p. 83-156.

BRASIL. Código Civil Brasileiro. Brasília: Senado Federal, 2002.

BRASIL. Constituição da República Federativa do Brasil de 1988. Brasília: Presidência da República, 1988. Disponível em: http://www.planalto.gov. br/ccivil_03/constituicao/ constituicaocompilado.htm. Acesso em: 20 set. 2020.

BRASIL. Lei $\mathbf{n}^{0} 6.938$ de 31 de agosto de 1981. Dispõe sobre a Política Nacional do Meio Ambiente, seus fins e mecanismos de formulação e aplicação, e dá outras providências. Brasília: Presidência da República, 1981. Disponível em: http://www.planalto.gov.br/ccivil_03/Leis/ L6938.htm Acesso em: 25 set. 2020.

BRASIL. Supremo Tribunal Federal. ADI-MC: 3540 DF, Relator: Celso de Mello, Data de Julgamento: 01/09/2005, Tribunal Pleno, Data de Publicação, 3 de fevereiro de 2006. Disponível em: https://stf.jusbrasil.com.br/jurisprudencia/763322/medida-cautelar-na-acao-direta-deinconstitucionalidade-adi-mc-3540-df. Acesso em: 14 out. 2020.

CANOTILHO, José Joaquim Gomes. Actos autorizativos jurídico-públicos e responsabilidade por danos ambientais. Boletim da Faculdade de Direito da Universidade de Coimbra, Coimbra, v. LXIX. p. 1-64, 1993.

CARVALHO, Daniela Marques. À procura de uma teoria de causalidade aplicável à responsabilidade civil ambiental. Revista de Direito Ambiental, São Paulo, ano 16, v. 62. 2011.

CARVALHO, Délton Winter de. Dano ambiental futuro: a responsabilidade civil pelo risco ambiental. Rio de Janeiro: Forense Universitária, 2008.

CIRNE, Mariana Barbosa. A Lei Complementar 140/2011 e as competências ambientais fiscalizatórias. Revista de Direito Ambiental, São Paulo, v. 18, n. 72, p. 67-116, out./dez. 2013.

CIRNE, Mariana Barbosa. Desvelando um Poder Executivo desenvolvimentista e avesso à Constituição verde: um estudo dos argumentos jurídicos e políticos nos vetos presidenciais em projetos de lei ambientais de 1988 a 2016. 2018. 412 f. Tese (Doutorado em Direito) Universidade de Brasília, Brasília, 2019.

FIORILLO, Celso Antônio Pacheco. Curso de direito ambiental brasileiro. São Paulo: Saraiva, 2009.

GAGLIANO, Pablo Stolze; PAMPLONA FILHO, Rodolfo. Novo curso de direito civil: responsabilidade civil. São Paulo: Saraiva, 2003. v. 3.

HUPFFER, Haide Maria et al. Responsabilidade civil do Estado por omissão estatal. Revista 
Direito GV, São Paulo, v. 8, n. 1, p. 109-129, jun. 2012. Disponível em: http://www.scielo.br/ scielo.php?script $=$ sci_arttext\&pid $=\mathrm{S} 180824322012000100005 \& \operatorname{lng}=\mathrm{en} \& \mathrm{nrm}=$ iso. Acesso em: 29 out. 2020. DOI: https://doi.org/10.1590/S1808-24322012000100005

LEITE, José Rubens Morato. Dano ambiental: do individual ao coletivo extrapatrimonial. São Paulo: Ed. RT, 2003.

LEUZINGER, Márcia Dieguez. Meio ambiente: propriedade e repartição constitucional de competências. Rio de Janeiro: Esplanada. 2002.

LEUZINGER, Márcia Dieguez; CUREAU, Sandra. Direito ambiental. Rio de Janeiro: Elsevier, 2008.

MACHADO, Paulo Affonso Leme. Competência comum, concorrente e supletiva em matéria de meio ambiente. Revista de Informação Legislativa, Brasília, v. 33, n. 131, p. 167-174, jul./set. 1996.

MELLO, Celso Antônio Bandeira de. Curso de direito administrativo. 14. ed. São Paulo: Malheiros, 2002.

MELLO, Celso Antônio Bandeira de. Curso de Direito Administrativo. 27. ed. São Paulo: Malheiros, 2010.

MILARÉ, Édis. Direito do ambiente: a gestão ambiental em foco: doutrina, jurisprudência, glossário. 6. ed. São Paulo: Revista dos Tribunais, 2008.

MOREIRA, Danielle de Andrade; LIMA, Letícia Maria Rêgo Teixeira; MOREIRA, Izabel Freire. O princípio do poluidor-pagador na jurisprudência do stf e do STJ: uma análise crítica. Veredas do Direito, Belo Horizonte, v. 16, n. 34, p. 367-432, maio 2019. Disponível em: http:// revista.domhelder.edu.br/index.php/veredas/article/view/1341/24736. Acesso em: 23 out. 2020.

OLIVEIRA, William Figueiredo de. Dano moral ambiental. Rio de Janeiro: Lumem Juris, 2007.

PEREIRA, Caio Mário da Silva. Responsabilidade civil. 9. ed. Rio de Janeiro: Forense, 2000.

PORFÍRIO JÚNIOR, Nelson de Freitas. Responsabilidade do Estado em face do dano ambiental. São Paulo: Malheiros, 2002.

RODRIGUES, Marcelo Abelha. Processo civil ambiental. São Paulo: Ed. RT, 2008.

SANTOS, Renato Augusto dos; BRASIL, Deilton Ribeiro. Responsabilidade civil ambiental: reflexões sobre sustentabilidade, compensação e prevenção. Revista do Direito Público, Londrina, v. 13, n. 3, p. 111-129, dez. 2018.

SARLET, Ingo Wolfgang; FENSTERSEIFER, Tiago. Direito Constitucional Ambiental: Constituição, direitos fundamentais e proteção do ambiente. São Paulo: Revista dos Tribunais, 2014.

SILVA, Luciana de Carvalho Salgueiro. Tutela jurisdicional preventiva e efetividade do direito fundamental do meio ambiente. 2011 Dissertação (Mestrado em Direito Público) - 
Universidade Federal de Alagoas, Maceió, 2011.

SIRVINSKAS, Luis Paulo. Manual de direito ambiental. 2. ed. São Paulo: Saraiva, 2010.

STEIGLEDER, Annelise Monteiro. Responsabilidade Civil Ambiental: as dimensões do dano ambiental no direito brasileiro. Porto Alegre: Livraria do Advogado, 2011.

TEIXEIRA, Sávio de Figueiredo. O meio ambiente. Revista Consulex, São Paulo, ano IV, n. 46, out. 2000.

Como citar: CIRNE, Mariana Barbosa; SILVA, Maycon Douglas de Miranda. Responsabilidade civil ambiental do Estado por omissão e o princípio do poluidor-pagador. Revista do Direito Público, Londrina, v. 16, n. 2, p. 221-239, ago. 2021. DOI: 10.5433/24157-108104-1.2021v16n 2p. 221. ISSN: 1980-511X 